\title{
The Control of Information Technology in the Moroccan Parliament Malik MOTII ${ }^{1}$, ALAMI SEMMA ${ }^{2}$, YOUSSEF AIT HOUAICH ${ }^{3}$
}

\author{
${ }^{1}$ Department of Mathematics and Computer Science, Faculty of Science and Techniques, Hassan 1st University, \\ Settat, Morocco
}

\author{
${ }^{2}$ Department of Mathematics and Computer Science, Faculty of science and Techniques, Hassan 1st University,
} Settat, Morocco

${ }^{3}$ The SIAD Laboratory, Hassan 1st University, ENCG, Settat, Morocco

\begin{abstract}
The control of Information technology in the Moroccan Parliament is of particular importance in contributing to the performance of the organization and guaranteeing the investments spent for the proper functioning of its activities and putting effective parliamentary work efficiently "good governance". However, these systems have not yet benefited from a model or approach to the exercise of this control and the implementation of its objectives, the theoretical study carried out in this research confirmed this observation. Corroborated by an empirical study based on the IT of the Moroccan Parliament, this exploration made it possible to identify the type and the level of control applied to this specific system in order to better elucidate the link between a "good control" and a "state of Performance "of an IT, and finally this study was the opportunity to propose perspectives for the resolution of this problem.
\end{abstract}

Keywords: Information technology, Moroccan Parliament, control, success, performance, ICT in Parliament.

\section{Introduction}

An information technology (IT) represents all the elements involved in the management, processing, transport and dissemination of information within the organization, including the organized set of resources (hardware, software, Personnel, data, procedures) to acquire, process, store information (in the form of data, text, images, sound, etc.) in and between organizations. According to Robert REIX, these ITs are indeed "a management object that must be finalized, organized and constructed, then animated and controlled". The control of the IT was born because its management is an issue for the manager. It is a matter of mastering a set of components that are at the same time technical, organizational and intellectual. The control of the IT evokes all the necessary measures to monitor and assist the manager, monitor the budget, establish reference standards and master the practices applied, all to ensure the success of the IT and to ensure an increased follow-up Performance and utility of the IT in the organization.
Even the great importance given by researchers to the problem of evaluation, control and governance of IT, this phase has not yet been sufficiently explored. Indeed, the first research in the field focuses mainly on problems of project management and design of computer applications and then take an interest in a new problem referring to a difficulty observed during the control of IT.

This issue of IT control (Robert REIX, 2004) concerns the general problem of the control "Why control an IT?" And the specific problem of evaluation and the operationalization of this control in the public sector in particular Our Moroccan parliament? on the other hand. Thus, in this study, it is the case to answer these two problems in a theoretical part and then to examine in an empirical part the nature of this control and its effect on the state of these systems in the Moroccan parliament.

\section{Literature review:}

\subsection{Why control IT?}

In a broad sense control consists of a large number of means which generally seek to "limit the arbitrariness of the parliamentary function" to make its activities conform to the missions and objectives of legislative responsibilities, government control, The evaluation of public policies and parliamentary diplomacy, in addition to strengthening parliamentary relations with constitutional institutions, good governance bodies, advanced regional workshops, civil society and citizens, Plan of ends or means. It is one of the essential tools for the good governance of the Moroccan parliament and one of the key processes by which "Government, parliamentarian, citizen and administration" can ensure; In absolute transparency; That resources are used effectively and efficiently to achieve the objectives and strategies outlined.

In a more restricted sense, the control of the IT for Robert REIX is the action that allows the control and the success of the conduct of the IT, this action implies in particular three measures (1) Measure the performance carried out in relation to the objectives; (2) Assess the quality of management actions and the use of resources; And (3) 
Motivate and guide the actors in a perspective of continuous improvement, thus organizational learning.

Indeed, the objectives of controlling an IT are numerous because the IT is an essential tool in the strategy of the organization and the investments devoted to the ICT are as estimable as the benefits that could be obtained. The reasons for the control are even more varied when we speak of a IT deployed in the Moroccan parliament where the control is more solicited; The risk of failure of its systems is higher and the issue of performance is more worrying.

\subsection{The quest for the success of the IT project}

A study by the United Nation Economic and Social Development and according to the results on their report, the rates of failure of e-government development projects range between $60 \%$ and $80 \%$. Given these results, it is "A massive waste of financial, human resources and political resources and the inability to provide the potential benefits of egovernment to its beneficiaries" According to Richard HEEKS. These failures have a high cost especially for developing countries, according to this researcher six categories of potential e-Gov failure costs can be identified: (1) direct financial costs, (2) direct and indirect financial costs; (3) opportunity costs; (4) political costs; (5) the costs of potential benefits and (6) future costs.

David BASCARINI mentions the absence of a standardized definition of the success of the IT project, as well as an accepted methodology to measure this success. The absence of a standard definition of failure has given rise to several interpretations of this variable which is exchanged from one researcher to another. For example, for Richard HEEKS, the success and failure of ICTs in developing countries can be categorized into four categories: (1) success; (2) failure of sustainability; (3) partial failure; (4) total failure.

This state of failure is returned according to Chantal MORLEY to the fact that the IT projects have the peculiarity of having the triplet: Objective, Means and Deadlines. Their degree of uncertainty is high, because the goal is not fully defined until its completion. To this end, the researcher has identified six IT risk factors that are: (1) the size of the project; (2) technical difficulty (3) degree of integration; (4) organizational configuration; (5) the intended change; (6) project team instability.

The Organization for Economic Co-operation and Development "OECD" in a study on the management of large ICT projects in the public sector and this is the case for our research "the Moroccan parliament" has identified three factors that can have an impact on (1) the nature of the project (the more the project impacts the organizational component, the more it is exposed to risk), (2) the size of the project, and finally ( 3 ) the management mode (the division of competences and prerogatives between organizations, the decision of the public contract, etc.).

\subsection{The quest for overall performance}

The analysis of the contribution of IT to performance has been the subject of a considerable number of studies such as analyzes of contribution to local performance and analyzes of contribution to overall organizational performance. Similarly, extensive literature has been produced to analyze the effects of ICT adoption within government, which has demonstrated the extent to which organizational performance is inseparable from the performance of ICT deployment.

Zeeva MILLMAN retains organizational effectiveness as the measure of organizational impact of an IT on the performance of the organization. It details three factors that are related to this organizational dimension: (1) improving productivity by the system, is the ability of the IT to help the organization to produce more outputs better quality; (2) the effectiveness of the system and its ability to assist the organization in solving management problems; And (3) the efficiency of the system and its ability to assist the organization in obtaining the greatest possible return on the resources used.

It is difficult to isolate or separate the specific effects of ICT investment from other factors affecting the performance of the organization (other investments,

external effects). But monitoring performance in general and that of IT in particular promotes the transparency of public action and provides citizens with information about the goals, costs and results of local services.

\subsection{How to control?}

Robert REIX points out that the control practices of the IT have developed "late and limited" and this is due to two reasons. The first one refers to users who resist control and the second reason is related to the nature of the IT itself Prevented the introduction of an integrated approach of control.

This delay has had an effect on the methods of control developed and on the question of the control of IT in general. In the literature review, the question of control is impacted by two questions.

The first is related to a problematic of the IT itself: "how to control a thing that is both tool and object? ". The IT is supposed to be subject to double control: (1) firstly, a control that responds to the need to evaluate the performance of a tool that participates in the performance of the Moroccan parliament as a support Available to users; Then (2) a control of the IT as an object realized by the Moroccan parliament that the latter must perfect and succeed so that this product concurs to its organizational performance and its strategic alignment.

The second question is conditioned by the diversity of control situations. (Robert REIX, 2004) (a control of the management of the IT department, an evaluation after implementation, an opportunity study or elaboration and the implementation of the IT Master Plan, etc.); By the diversity of control objects (means used, product and service offered, processes, results, etc.) per desired level of control (strategic, organizational, application) and the timing of such control (a priori, Posterior). These variations thus generate several types of control which may be either institutionalized or take the form of periodic or occasional controls. In practice, the different types of control cited can be distributed over the life cycle of the IT: this gives pre-control to an IT project, control during the IT project until its implementation and a control after the implementation of the IT project. IT or functional IT control 
The following table cites the control dimensions of an IT collected from the review of the literature:

Table 1: the control dimensions of an information technology

\begin{tabular}{|c|c|c|c|c|}
\hline 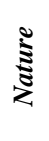 & $\underbrace{-1}_{\Delta}$ & $\frac{\tilde{\Xi}}{\stackrel{\Xi}{0}}$ & 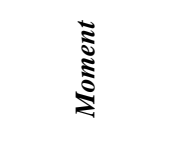 & 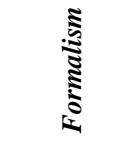 \\
\hline$\underset{\Xi}{\stackrel{\Xi \Xi \Xi}{\Xi}}$ & $\begin{array}{l}\text { Strategic (piloting, } \\
\quad \text { planning, } \\
\text { Indicators, Risk) } \\
\text { Organizational } \\
\text { (Governance, } \\
\quad \text { structure) } \\
\text { Applicative and } \\
\quad \text { functional (base } \\
\quad \text { of Data, code, } \\
\quad \text { software, } \\
\text { architecture, etc. }\end{array}$ & \begin{tabular}{l} 
Process \\
Results \\
Performa \\
nce \\
Success \\
Budget \\
Satisfacti \\
on \\
Use \\
Quality \\
IT \\
Security, \\
and so \\
\multicolumn{1}{c}{ on. }
\end{tabular} & $\begin{array}{l}\text { - A priori } \\
\text { control: } \\
\text { Opportunit } \\
\text { y Study, } \\
\text { the Inform } \\
\text { ation Tech } \\
\text { nology Ma } \\
\text { ster Plan } \\
\text { - Project flow } \\
\text { control } \\
\text { - Ex-post } \\
\text { control }\end{array}$ & $\begin{array}{l}\text { Initiative } \\
\text { Periodic } \\
\text { Institution } \\
\text {-alized } \\
\text { Audit } \\
\text { Inspectio } \\
\text { Mandate } \\
\text { Certificat- } \\
\text { ion }\end{array}$ \\
\hline
\end{tabular}

The preliminary control of a IT project or the control during the course of a IT project can be internal or external, relate to one or more objects, operate at different levels and take one of the formal forms of control. However, in the Moroccan parliament, the prior control or the control of progress have no models or tools studied and validated by the body of the researchers. Some countries have developed evaluation and internal steering tools for successful IT projects. During these two phases, post project evaluations where IT is already operational are fairly diverse. They vary according to the nature, the object of the control, the level of control as well as its degree of formalism. In this sense, each researcher has attempted to provide a good practice reference framework for the success of an IT and to set up a global scale to measure its success and estimate its performance.

The control approaches studied allow us to formulate three main observations: (1) the control of IT is generally placed posteriorly, that is, after the IT implantation phase; (2) the absence of a common criterion for judging the success and status of the IT; (3) the existence of e-government control methods that focus on evaluating e-services and do not take into account other ITs that are widespread in the administration (IT back office and IT middle office).

\subsection{Limits to IT control}

There are several limitations to making the issue of IT control in the Moroccan Parliament more difficult. The limits identified in the literature studied and which may have an impact on the quality of control of these systems in the Moroccan parliament can be summarized as follows:

First, control in the Moroccan parliament is conditioned by the motivation of politicians and leaders rather than their submission to control by quoting the Secretary-General. Public choice theorists refer to discretionary control and the great freedom of management enjoyed by those responsible even though they are subject to accountability in accordance with the responsibilities entrusted to them by elected officials. Second, there is a modest and embryonic literature on the control of ITs in the Moroccan parliament compared with those of the private sector and other parliaments. Some researchers refer the lack of IT evaluation in this sector to a medium and voluntary issue, those who are willing to evaluate, such as academics, often lack resources and capacity and those who have the resources Such as leaders lack the will to evaluate.

Finally, there are a number of obstacles to assessing and measuring the success of e-governments (OECD, 2007). These include (1) lack of evaluation culture as a major barrier; (2) the absence of a common definition of costs and benefits, (3) the lack of competence necessary for the evaluation action, (4) the unavailability of a clear and determined indicator, (5) Of data collection on results, and (6) the lack of a methodology for the evaluation approach.

\section{Methodology}

In order to intensify the issue of IT control in the Moroccan Parliament in order to achieve a higher level of maturity, an efficient Information technology and very good IT governance beyond the theoretical framework of this research, A study that focuses on the Information Technology Directorates (ITDs) in the Moroccan parliament. The empirical study was based on a questionnaire survey that takes into account the current state of the Information technology, the type of IT control, and a literature review. The performance of the IS (balance sheet, feedback, audit report, press article, the IT Master Plan, etc.). The survey targeted the IT of the Moroccan Parliament based on six technological sectors to assess the state of its own technological level:

$\square$ Supervision and management of ICT;

$\square$ Infrastructure, services, applications and training;

$\square$ Systems and standards for the creation of legislative documents and information;

$\square$ Library and research services;

$\square$ Parliamentary websites;

$\square$ Communication between citizens and parliament.

The survey will identify:

$\square$ Insufficiencies of IT in the Moroccan parliament;

$\square$ Diagnose its current status;

$\square$ The types of IT control practiced and adopted in the Moroccan parliament;

$\square$ The level of ICT practice in both chambers.

The final objective is to determine the type of control of IT in the Moroccan parliament by the questionnaire and to establish the correlative relationship between the current state of the IT by the documentary analysis and a good control of these IT.

\section{Result and discussion}

\subsection{The results}


The investigation showed major shortcomings in the Information technology of the Moroccan parliament in both chambers and among these failures we can cite:

- Lack of a procedures manual;

- abandoned, unexploited, suspended, unfinished, delayed IT projects, etc. And the cause: insufficient internal control, budget and a strategic vision at the level of IT;

- Mismanagement of IT projects, subcontracting, formulation of maintenance contracts and their execution, control of investments, establishments, SPC;

- Poor division of powers and prerogatives between organizations, market decision-making;

- Lack of internal board;

- Absence of management tools, insufficient security, low integration;

- Low rate of ICT staff;

- weaknesses and delays in the e-Gov strategy and mixed results due to poor governance of IAS;

- Investments oriented 'Office equipment' rather than 'infrastructure', 'services', 'software' and 'training';

- Weakness in system integration, software development, hardware development, IT project reorganization, training and development, information processing;

- Lack of follow-up;

- Lack of internal communication also alignment IT with the strategic plan of the parliament of the two chambers;

- Lack of skills and continuing education, infrastructure problem;

- No external control "The parliament exempt from the control of state commitments and expenses" and any state control;

- Etc

Table 2: At the level of ICT in Moroccan parliament

\begin{tabular}{|l|c|c|}
\hline \multirow{2}{*}{ Section } & \multicolumn{2}{|c|}{ Percentage Score by Section } \\
\cline { 2 - 3 } & $\begin{array}{c}\text { House of } \\
\text { Representatives }\end{array}$ & $\begin{array}{c}\text { House of } \\
\text { Counsellors }\end{array}$ \\
\hline $\begin{array}{l}\text { Supervision and management } \\
\text { of ICT }\end{array}$ & 46 & 12.7 \\
\hline $\begin{array}{l}\text { Infrastructure, Services, } \\
\text { Applications and Training }\end{array}$ & 67.8 & 48.3 \\
\hline $\begin{array}{l}\text { Systems and standards for the } \\
\text { creation of legislative } \\
\text { documents and information }\end{array}$ & 60 & 23.3 \\
\hline Library and research services & 50 & 29 \\
\hline Parliamentary websites & 60 & 21.4 \\
\hline $\begin{array}{l}\text { Communication between } \\
\text { citizens and parliament. }\end{array}$ & 33.3 & $\mathbf{2 2 . 9 7 \%}$ \\
\hline Percentage Score per Room & $\mathbf{5 3 . 2 5 \%} \%$ \\
\hline Percentage Score Parliament & \multicolumn{2}{|c|}{$\mathbf{3 8 . 1 1 \%}$} \\
\hline
\end{tabular}

Table 3: At the level of the IT control in Moroccan parliament

\begin{tabular}{|c|c|c|c|c|}
\hline \multicolumn{4}{|c|}{ 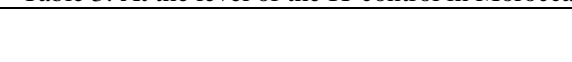 } & $\begin{array}{l}\text { Type of } \\
\text { control }\end{array}$ \\
\hline \multirow{2}{*}{$\begin{array}{c}\text { A } \\
\text { priori } \\
\text { control }\end{array}$} & \multirow{2}{*}{$\begin{array}{l}\text { Internal } \\
\text { control }\end{array}$} & Object & $\begin{array}{c}\text { Budget } \\
\text { use }\end{array}$ & Initiative \\
\hline & & $\begin{array}{c}\text { Control } \\
\text { level }\end{array}$ & $\begin{array}{c}\text { Strategic } \\
\text { Organizational }\end{array}$ & Initiative \\
\hline \multirow{2}{*}{$\begin{array}{c}\text { Project } \\
\text { flow } \\
\text { control }\end{array}$} & \multirow{2}{*}{$\begin{array}{c}\text { Internal } \\
\text { control }\end{array}$} & Object & $\begin{array}{c}\text { Process } \\
\text { Planning }\end{array}$ & Initiative \\
\hline & & $\begin{array}{c}\text { Control } \\
\text { level }\end{array}$ & $\begin{array}{c}\text { Strategic } \\
\text { Application }\end{array}$ & Initiative \\
\hline \multirow[t]{2}{*}{$\begin{array}{c}\text { Ex- } \\
\text { post } \\
\text { control }\end{array}$} & \multirow[t]{2}{*}{$\begin{array}{l}\text { Internal } \\
\text { control }\end{array}$} & Object & $\begin{array}{c}\text { Budget } \\
\text { Satisfaction } \\
\text { Planning } \\
\text { security }\end{array}$ & $\begin{array}{l}\text { Periodic } \\
\text { Initiative } \\
\text { Initiative } \\
\text { Initiative }\end{array}$ \\
\hline & & $\begin{array}{c}\text { Control } \\
\text { level }\end{array}$ & $\begin{array}{c}\text { Strategic } \\
\text { Application }\end{array}$ & Initiative \\
\hline
\end{tabular}

\subsection{Discussion of results}

The survey and the field audit make it possible to identify several shortcomings of the IT both at the front office and back office levels.

Internal evaluations of back-office IT have shown that there are several cases of failure (IT projects abandoned, unexploited, pending, incomplete, delayed, lack of budget, misconduct of IT projects by ITD managers etc.); Budgetary slippages with no specific follow-up and management problems of ITDs (computerization on the initiative of the leaders and politicians, lack of policy on IT and a long and short term strategy, etc.). A certain state of failure of projects IT.

The criticism is pointed to a lack of actions and control tools for these systems, as ITDs benefit from an advanced degree of autonomy in the absence of a national authority that supports the harmonization of this technology.

The weaknesses of the Morocco e-Gov strategy and the mixed results are the result of poor governance according to the Economic, Social and Environmental Council, this is explained more by the ranking of the e-government of Morocco 99/148 By the IMF (2014) and 120/193 by the United Nations (UN, 2012) and this weakness, affects the framework of IT projects at parliamentary level, except the House of Representatives has received an external grant, Has helped to restructure the infrastructure and build a database of the Parliament's archive since 1950.

The survey highlighted the predominance of traditional control (lack of a strategy for IT, budget, communication between the parliamentary entities and that for both chambers, public procurement, formality, administrative procedures, infrastructure, Human resources, etc.) of IT projects to the detriment of formal control covering all stages of the IT life cycle and covering all objects and levels of control.

Indeed, the first phase of the life of an IT is marked by internal controls that have as object the budget of the project and the formalities of procurement according to the laws in force. The rest of the control types are abandoned with imitation of the ITD and no external control is envisaged in this case. During the project, the Steering Committee and the Financial Affairs and Human Resources Directorate jointly execute the contract and ensure strategic control (compliance with milestones and 
deadlines, risks, etc.) and the IT application the product version). Finally, the last phase, the ITs are not systematically subjected to a post-project evaluation, except on the initiative of the ISD itself (measure of satisfaction, planning, security of the IT).

In addition, the ITs in the Moroccan parliament suffer from certain deficiencies identified during the documentary analysis. This questioning of their current status is accentuated more by the predominance of the traditional control of IT projects and the non-institutionalization of the other types and the Levels of control mentioned in the review of the literature

\section{Conclusion}

The literature examined the state of the art on the issue of IT control in general and that of the Moroccan parliament in particular and concluded that despite the importance of this practice of "good governance" Does not have a standard and unanimous control model and most models are interested in the question of user satisfaction and evaluation of the success of the IT in relation to the final product, whereas an a priori assessment triggered in The first stage of the life of the IT where it is still in its embryonic state would probably have a great impact on the end result. Thus, in the absence of this model, these systems are developed and exploited from a voluntarist perspective without being sufficiently controlled. The practical study of the case of the IT of the Moroccan parliament has confirmed this conclusion. On the one hand the diagnosis of the IT questioned their "current state", the balance sheet of the types of control exercised on the IT in Morocco led us to conclude that with a control predominant "market", which does not cover The internal functioning of the ITDs, which does not take a solemn form by the supervisory bodies and does not arm itself with adequate tools and standards, on the other hand, the efforts deployed risk being penalized by all these factors and The IT will be threatened either by failure in its "project" state or by a deficit of operation after its implantation. The field study showed that mastering this technology both in its "project" state and in its "functional" state in the Moroccan parliament requires follow-up instituted through the implementation of a competent structure and development A model and appropriate tools to take advantage of these promising technologies for the Moroccan parliament. The government must first ensure an adequate budget for the parliamentary Information technology, then provide parliament with documentation and information on its activities in a transparent manner and subsequently strengthen the structural relationship of its ministerial departments with the commissions and parliamentary groups.

\section{References:}

[1] BURLAUD Alain, GERMAK Philippe, « Management des SI : Manuel et applications », Editions Eyrolles, 2006, page 15 .

[2] David Autissier, Valerie Delaye, Mesure de la performance, Les biometrie de la performance, Groupe Eyrolles, 2008 ISBN : 978-2-212-54116-8

Heeks, R. (2006). Implementing and Managing e-

Government, Sage Publications, London.
[3] Heeks, R. (2008). Success and Failure Rates of eGovernment in Developing/Transitional Countries, [online], http://www.egov4dev.org/success/sfrates.shtml dgdhgh. [4] Asgarkhani, M. (2005). Digital government and its effectiveness in public management reform. Public Management Review (7).

[5] D. Bascarini, D. (1999). The Logical Framework for Defining Project Success.

[6] Project Management Journal, 30(4), pp. 25 - 32.

CES. (2013). La gouvernance des servcies publics. Consulté le $\quad 12 \quad 3, \quad 2013, \quad$ sur $\quad$ ces.ma: http://www.ces.ma/Documents/PDF/Avis-AS13_2013-

VF.pdf Danziger, J., \& Andersen, K. (2002). The impacts of information technology on public administration: an analysis of empirical research from the 'golden age' of transformation. International Journal of Public Administration.

[7] DeLone, W., \& McLean, E. (2003). The DeLone and McLean model of Information technologys success: A ten year update. Journal of Management Information technologys, 19(4).

[8] FEM. (2014). The Global Information Technology Report 2014. Consulté le 4 25, 2014, sur weforum.org: http://www3.weforum.org/docs/WEF_GlobalInformationTe chnology_Report_2014.pdf.

[9] N, FARAH (2014), le contrôle des systèmes d'information dans le secteur public: cas du Maroc. European Scientific Journal, ESJ, August 2014 edition vol.10, No.23 ISSN: 1857 - 7881 (Print) e - ISSN 18577431.

[10] Fisher, J. (2001). User satisfaction and system success: Considering the development team. Australian Journal of Information technologys, 9(1), pp. $21-29$.

[11] Evaluation des politiques e-gouvernement, rapport des Critiques et reproches de la politique e-Maroc 2010, programme Maroc numérique 2013.

http://www.courdescomptes.ma/upload/MoDUle_20/File_20 137.pdf.

[12] Griffin, D., \& Halpin, E. (2005). An exploratory evaluation of UK local egovernment from an accountability perspective. The Electronic Journal of eGovernment, 3(1), pp. 13-28.

[13] Gupta, M., Bhattacharya, J., \& Agarwal, A. (2007). Evaluating egovernment. Universities Press.

[14] Heeks, R. (2002). Information technologys and Developing Countries: Failure, Success, and Local Improvisations. The Information Society, 2(18), pp. 101112.

[15] Heeks, R. (2003). Most EGovernment-for-development Projects Fail: How Can Risks be Reduced? eGovernment Working Paper Series (14).

[16] IGF. (2010, janvier). RAPPORT DE SYNTHESE: AUDIT DE PERFORMANCE Exercices 2007 et 2008. Consulté le 9 12, 2013, sur www2.finances.gov.m: http://www2.finances.gov.ma/docs_internet/esp_doc/2010/i gf/3215_rapport_synthese_performance.pdf

[17] Li, E. (1997). Perceived importance of Information technology success factors: a meta-analysis of group differences. Information and Management. Mercier, J. (2001). L'administration publique de l'école classique au nouveau management public. Canada: la presse de l'université de Laval. Millman, Z. e. (1987). The impact of 
automated office systems on middle managers and their work. MIS Quaterly, 4(11).

[18] MMSP. (2010, Octobre). Rapport de synthèse: Cartographie de l'utilisation des TIC dans les secteurs publics au titre de l'année 2009. Consulté le 11 25, 2013, sur mmsp.gov.ma:

http://www.mmsp.gov.ma/carto2009/ressources/Synthesefr. pdf

[19] Morley, C. (2008). Management d'un projet système d'information, Principes, techniques, mise en œuvre et outils. Paris: Dunod.

[20] OCDE. (2000, Octobre 26-27). GESTION DES GRANDS PROJETS TI DANS LE SECTEUR PUBLIC: DEFINITIONS PRATIQUES. Consulté le 23, 2013, sur search.oecd.org/:

http://search.oecd.org/officialdocuments/displaydocumentp df $/$ ?cote $=$ PUMA/

MIT\%282000\%291\&docLanguage $=\mathrm{Fr}$

OCDE. (2007). Measuring and Evaluating E-Government in Arab Countries.Consulté le 5 15, 2013, sur http://www.oecd.org:

http://www.oecd.org/mena/governance/39856235.pdf .

[21] Poon, P., \& Wagner, C. (2001). Critical Success Factors Revisited: Success and Failure Cases of Information technology for Senior Executives. Decision Support System, 30(30), pp. 393-418.

[22] Reix, R. (2004). Systèmes d'Information et management des organisations. Paris: Edition Vuibert, édition 5.

[23] Reix, R., Fallery, B., Kalika, M., \& Rowe, F. (2011). Systèmes d'information et management des organisations. Vuibert.

[24] Ronaghan, S. A. (2002, Mai). Benchmarking Egovernment:A Global Perspective: assessing the progress of the UN Member States. United Nations Division of public Economic and Public administration and American society for public Administration. Consulté le 7 3, 2013, sur http://unpan1.un.org:

http://unpan1.un.org/intradoc/groups/public/documents/un/u npan021547.pdf

MALIK MOTII is a Ph.D. student 'The IT governance for the Moroccan Parliament', Department of Mathematics and Computer Science, Faculty of Science and Technology, Hassan 1 University, Settat, Morocco. Currently an engineer specialized in networks and information systems, information technology manager networks of information systems in the house of Counselors, Moroccan parliament.

ALAMI SEMMA is a Ph.D. in Faculty of Science and Technology, Hassan 1 University, Settat, Morocco. He is a qualified professor in electrical engineering.

YOUSSEF AIT HOUAICH is took his Ph.D. in computer science at the computer science department of Hassan I in 2016. His research areas include Open Source Technology and information theory. 